\title{
MISTAKE ANALYSIS OF MA STUDENTS SOLVE MATH MATHEMATICS ON POLYNOMIAL MATERIALS
}

\author{
Rani Oktaviani \\ SMKN 1 Cisarua, Jl. Kolonel Masturi No.300 \\ ranioktaviani1997@gmail.com
}

\begin{abstract}
This research aims to determine (1) to find out the average percentage of each type of error in solving polynomial problems (2) to find out the type of error most done by students in solving polynomial problems. The subjects of this study were all students of class XII in one MA in Cimahi City in the 2019/2020 school year, totaling 22 people. This research uses a qualitative approach and descriptive method. The results of this study indicate the type of error is the largest operation error, this is because students are less thorough and in a hurry in the calculation process. Meanwhile, generally the thing that causes students to make mistakes is not understanding the concept by writing incorrect formulas, procedures / steps that are used less precisely, and not careful when performing operations.
\end{abstract}

Keywords: Error, Mathematics, Polynomial

\begin{abstract}
Abstrak
Tujuan penelitian ini yaitu (1) untuk mengetahui presentase rata-rata setiap jenis kesalahan dalam menyelesaikan soal polinomial (2) untuk mengetahui jenis kesalahan paling banyak yang dilakukan oleh siswa dalam menyelesaikan soal polinomial. Subjek penelitian ini adalah seluruh siswa kelas XII di salah satu MA di Kota Cimahi tahun ajaran 2019/2020 yang berjumlah 22 orang. Penelitian ini menggunakan pendekatan kualitatif dan metode deskriptif. Hasil penelitian ini menunjukkan jenis kesalahan tersebesar adalah kesalahan operasi, hal ini karena siswa kurang teliti dan terburu-buru dalam proses perhitungan. Sedangkan, umumnya hal yang menyebabkan siswa melakukan kesalahan adalah kurang memahami konsep dengan menuliskan rumus yang tidak tepat, prosedur/langkah-langkah yang digunakan kurang tepat, dan tidak teliti saat melakukan operasi.
\end{abstract}

Kata Kunci: Kesalahan, Matematika, Polinomial

How to Cite: Oktaviani, R. (2020). Mistake Analysis Of Ma Students Solve Math Mathematics On Polynomial Materials. JEE, 3 (1), 25-30. 


\section{INTRODUCTION}

Since the enactment of the 2013 curriculum, mathematics for MIA majors is divided into two namely compulsory mathematics and specialization mathematics. Specialization mathematics is studied by students from class X to class XII. That means that students are required to understand and learn the available material. One of the subjects in class XI semester 2 is polynomials. This material is one of the scopes of algebra material. In addition, this algebra material has been taught since junior high school. Besides the existence of algebra as one of the fundamental things in mathematics. Algebra learning in schools aims to enable students to think logically, analytically, systematically, critically, creatively, and collaboratively.

The low mathematical ability of students can be seen from students' mastery of the material that has been learned. Student mistakes in solving problems can be one way to know the extent to which students master the material. Therefore, it is necessary to analyze errors to find out the factors that cause students to make mistakes which will be useful to find solutions to solve and improve learning in the future.

According to Nasution \& Irwan (2017), the results of research at SMA Negeri 1 Aek Kuasan in solving the remaining theorem concept questions are students having difficulty determining the appropriate formula because students do not understand the concept of questions, student difficulties are seen in the lack of accuracy of students in solving problems, and students less thorough in the calculation process. Therefore, polynomials are material that requires reasoning and is not enough to just memorize it. Students must understand the concepts of the formulas presented so that they can solve the problem well and in the end can be seen as a picture of student understanding. The types of errors that will be examined in this study are grouped into three according to Herman Hudoyo (Aly, Sujadi, \& Taufiq, 2019), namely concept errors, procedural errors, and operating errors.

The purpose of this research is (1) to find out the average percentage of each type of error in solving polynomial problems (2) to find out the most types of mistakes made by students in solving polynomial problems.

\section{METHOD}

This research uses a qualitative approach and descriptive method. Arikunto (2010:3) explains that descriptive research is research intended to investigate the circumstances, conditions or other things that have been mentioned, the results of which are presented in the form of research reports.

The subjects of this study were all students of class XII in one MA in Cimahi City in the academic year 2019/2020, amounting to 22 people. Data collection techniques using the test. This research instrument uses a test in the form of four mathematical description questions with polynomial material. Data analysis techniques using the interactive analysis model of Miles and Huberman include data collection, data reduction, data presentation, and drawing conclusions (Sugiyono, 2013) 


\section{RESULTS AND DISCUSSION}

\section{Results}

Based on data analysis, the percentage of students' mistakes in working on polynomial math problems is as follows.

\section{Concept Error}

Table 1. Percentage of Concept Mistakes

\begin{tabular}{|c|c|c|}
\hline \multirow{2}{*}{ Problem number } & \multicolumn{2}{|c|}{ Students answer questions } \\
\hline & amount & Percentage \\
\hline 1 & 13 & $59,06 \%$ \\
\hline 2 & 14 & $63,63 \%$ \\
\hline 3 & 17 & $77,27 \%$ \\
\hline 4 & 15 & $68,18 \%$ \\
\hline \multicolumn{2}{|c|}{ Average } & $67,03 \%$ \\
\hline
\end{tabular}

Here is an example of a student's mistake is to make a concept error, students do not write the right formula to solve the problem so that what is answered does not match what is meant by the problem. This is due to students not understanding the meaning of the questions.

Figure 1. Example of a student making a concept error.

Error Procedure

Table 2. Percentage of Procedure Errors

\begin{tabular}{ccc}
\multirow{2}{*}{ Problem number } & \multicolumn{2}{c}{ Students answer questions } \\
\cline { 2 - 3 } & amount & Percentage \\
\hline 1 & 13 & $59,06 \%$ \\
2 & 14 & $63,63 \%$ \\
3 & 19 & $86,36 \%$ \\
4 & 15 & $68,18 \%$ \\
\hline & & $68,03 \%$ \\
\hline
\end{tabular}

The following is an example of a student's mistake: making a procedural error by not completing the completion steps. The result of solving the problem should include the value of an in the polynomial and finally, look for other linear factors of the polynomial.

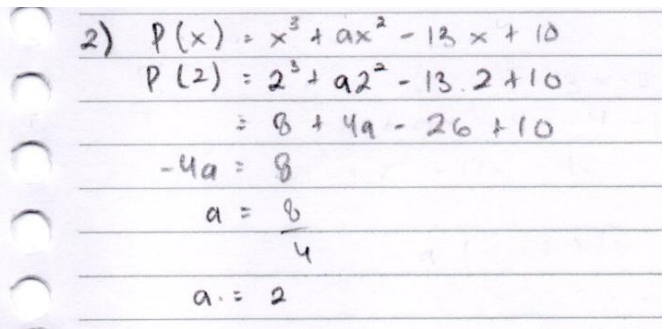

Figure 2. Example of a student making a procedural error. 
Operation Error

Table 3. Percentage of Operating Errors

\begin{tabular}{ccc}
\hline \multirow{2}{*}{ Problem number } & \multicolumn{2}{c}{ Students answer questions } \\
\cline { 2 - 3 } & amount & Percentage \\
\hline 1 & 14 & $63,63 \%$ \\
2 & 17 & $77,27 \%$ \\
3 & 18 & $81,81 \%$ \\
4 & 16 & $72,71 \%$ \\
\hline & Average & $73,85 \%$ \\
\hline
\end{tabular}

Here is an example of a student's mistake: making an operation error subtracting $8 b-4 b$ into $2 \mathrm{~b}$. This is due to students not careful and in a hurry in the calculation process.

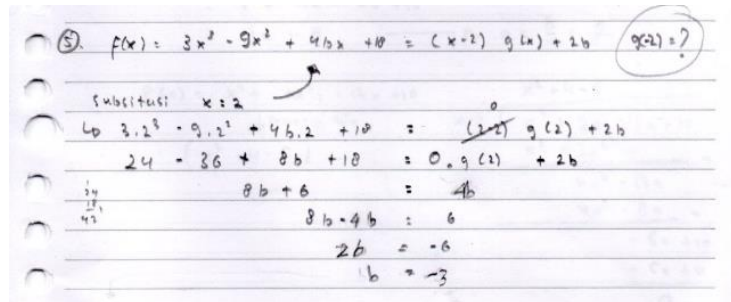

Figure 3. Example of a student making an operation error

\section{Discussion}

\section{Concept Error}

Understanding the concept needs to be owned by every student. According to Widjajanti (Hutajulu, Senjayawati, \& Minarti, 2019), conceptual understanding is an understanding of mathematical concepts, students can learn new ideas by linking these ideas to the knowledge that their prerequisites have. The indicator of concept errors is not writing what is known in the problem, not writing what is asked in the problem and using the formula that is not appropriate (Istiqomah, 2016). From the results of data analysis, the average student made a concept error that is equal to $67.03 \%$. The highest concept error is in item number 3 at $77.27 \%$. While the lowest concept error found in item number 1 was $59.06 \%$.

\section{Error Procedure}

According to ("Big Indonesian Dictionary," n.d.) procedure, which is the stage of activities to complete an activity or method step by step with certainty in solving a problem. The Indicator of procedural error is irregularity in writing or sorting steps in completion (Istiqomah, 2016). From the results of data analysis, the average student made a procedural error that is equal to $68.03 \%$. The highest procedure error is in item number 3 of $86.36 \%$. While the lowest procedure error is in item number 1 of $59.06 \%$.

\section{Operation Error}

Operation error indicator is wrong in making calculations and the final results are less precise (Istiqomah, 2016). From the results of data analysis, the average student made an operation error of $73.85 \%$. The highest procedure error is in item number 3 at $81.81 \%$. While the lowest operation error is in item number 1 of $63.63 \%$. 
In general, problem number 3 is the biggest error problem out of the 3 types of errors and problem number 1 is the smallest problem out of the 3 types of errors. The thing that causes students to make mistakes is not understanding the concept by writing incorrect formulas, procedures/steps that are used less precisely, and not careful when performing operations. This is in line with what was expressed by Ario (Lestari, Aripin, \& Hendriana, 2018) who said that the problems that occur in students are not careful in understanding problems, doing calculations, and forgetting formulas. In addition, Sulistiawati (Lestari et al., 2018) also revealed that the majority of students' answers to errors were in determining the steps of work because students were less accustomed to working on mathematical reasoning questions.

\section{CONCLUSION}

Based on the results of the research discussion, conclusions can be drawn

1. The biggest type of error is an operation error, this is because students are less thorough and rush in the calculation process.

2. In general, the things that cause students to make mistakes are not understanding the concept by writing incorrect formulas, procedures/steps that are used less precisely, and not careful when performing operations.

\section{REFERENCES}

Aly, B. F. N., Sujadi, A. ., \& Taufiq, I. (2019). Analisis Kesalahan Dalam Menyelesaikan Soal Matematika Pada Siswa Kelas X SMK Negeri 1 Seyegan. UNION:Jurnal Pendidikan Matematika, 7(1), 135-144.

Arikunto, S. (2010). Prosedur Penelitian Suatu Pendekatan Praktik. Jakarta: Rineka Cipta.

Hutajulu, M., Senjayawati, E., \& Minarti, E. D. (2019). Analisis Kesalahan Siswa SMK Dalam Menyelesaikan Soal Kecakapan Matematis Pada Materi Bangun Ruang. Mosharafa : Jurnal Pendidikan Matematika, 8.

Istiqomah, N. (2016). MATEMATIKA SISWA KELAS XI SMK TAMTAMA KARANGANYAR TAHUN AJARAN 2013 / 2014. UNION : Jurnal Pendidikan Matematika, 4(2), 343-352.

Kamus Besar Bahasa Indonesia. (n.d.). Retrieved January 29, 2020, from https://kbbi.kemdikbud.go.id/entri/prosedur

Lestari, S. A., Aripin, U., \& Hendriana, H. (2018). Analisis Kesalahan Siswa SMP Berdasarkan Newman dalam Menyelesaikan Soal Kemampuan Berpikir Kritis Matematis pada Materi Bangun Ruang Sisi Datar. JPMI (Jurnal Pembelajaran Inovatif Matematika), 1(1), 71. https://doi.org/10.24014/juring.v1i1.4912

Nasution, I. P., \& Irwan. (2017). ANALISIS KESULITAN SISWA PADA MATERI TEOREMA SISA DI SMA NEGERI 1 AEK KUASAN. Mathematic Paedagogic, II(1), 69-74.

Sugiyono. (2013). Penelitian Pendidikan: Pendekatan Kuantitatif dan Kualitatif, dan R\&D. Bandung: Alfabeta. 
Oktaviani, Mistake Analysis Of Ma Students Solve Math Mathematics On ... 